\title{
Size-distributions of $n$-alkanes, PAHs and hopanes and their sources in the urban, mountain and marine atmospheres over East Asia
}

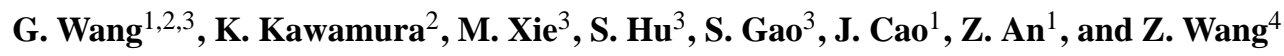 \\ ${ }^{1}$ State Key Laboratory of Loess and Quaternary Geology, Institute of Earth Environment, Chinese Academy of Sciences, \\ Xi'an 710075, China \\ ${ }^{2}$ Institute of Low Temperature Science, Hokkaido University, Sapporo 060-0819, Japan \\ ${ }^{3}$ School of the Environment, State Key Laboratory of Pollution Control and Resources Reuse, Nanjing University, \\ Nanjing 210093, China \\ ${ }^{4}$ Institute of Atmospheric Physics, Chinese Academy of Sciences, Beijing 100029, China
}

Received: 30 May 2009 - Published in Atmos. Chem. Phys. Discuss.: 24 June 2009

Revised: 8 October 2009 - Accepted: 9 November 2009 - Published: 23 November 2009

\begin{abstract}
Size-segregated (9 stages) $n$-alkanes, polycyclic aromatic hydrocarbons (PAHs) and hopanes in the urban (Baoji city in inland China), mountain (Mt. Tai in east coastal China) and marine (Okinawa Island, Japan) atmospheres over East Asia were studied using a GC/MS technique. Ambient concentrations of $n$-alkanes $\left(1698 \pm 568 \mathrm{ng} \mathrm{m}^{-3}\right.$ in winter and $487 \pm 145 \mathrm{ng} \mathrm{m}^{-3}$ in spring), PAHs $(536 \pm 80$ and $161 \pm 39 \mathrm{ng} \mathrm{m}^{-3}$ ), and hopanes ( $65 \pm 24$ and $20 \pm 2.4 \mathrm{ng} \mathrm{m}^{-3}$ ) in the urban air are 1-2 orders of magnitude higher than those in the mountain aerosols and 2-3 orders of magnitude higher than those in the marine samples. Mass ratios of $n$ alkanes, PAHs and hopanes clearly demonstrate coal-burning emissions as their major source. Size distributions of fossil fuel derived $n$-alkane, PAHs and hopanes were found to be unimodal in most cases, peaking at $0.7-1.1 \mu \mathrm{m}$ size. In contrast, plant wax derived $n$-alkanes presented a bimodal distribution with two peaks at the sizes of $0.7-1.1 \mu \mathrm{m}$ and $>4.7 \mu \mathrm{m}$ in the summer mountain and spring marine samples. Among the three types of samples, geometric mean diameter (GMD) of the organics in fine mode $(<2.1 \mu \mathrm{m})$ was found to be smallest (av. $0.63 \mu \mathrm{m}$ in spring) for the urban samples and largest $(1.01 \mu \mathrm{m})$ for the marine samples, whereas the GMD in coarse mode $(\geq 2.1 \mu \mathrm{m})$ was found to be smallest $(3.48 \mu \mathrm{m})$ for the marine aerosols and largest $(4.04 \mu \mathrm{m})$ for the urban aerosols. The fine mode GMDs of
\end{abstract}

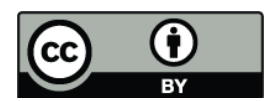

Correspondence to: $\mathrm{G}$. Wang (wanggh@ieecas.cn) the urban and mountain samples were larger in winter than in spring and summer. Moreover, GMDs of 3- and 4-ring PAHs were larger than those of 5- and 6-ring PAHs in the three types of atmospheres. Such differences in GMDs can be interpreted by the repartitioning of organic compounds and the coagulation and hygroscopic growth of particles during a long-range transport from the inland continent to the marine area, as well as the difference in their sources among the three regions.

\section{Introduction}

Atmospheric aerosols influence climate directly by scattering and absorbing radiation, and indirectly by modifying the optical properties and lifetime of clouds via acting as cloud condensation nuclei (Albrecht, 1989; Ramanathan, 2001). Airborne particles contain toxic matters such as heavy metals and organic pollutants, thus are deeply linked with human health (Dockery et al., 1993; Finlayson-Pitts and Pitts Jr, 2000; Anderson, 2009). Organic compounds constitute a substantial fraction of atmospheric aerosols. Especially for fine particles less than $2 \mu \mathrm{m}$ in diameter, 20-90\% of the mass is carbonaceous (Seinfeld and Pankow, 2003; Kanakidou et al., 2005).

Aerosol sources in East Asia are different from those in Europe and North America, because much more coal and biomass are burned with minimal emission controls in some

Published by Copernicus Publications on behalf of the European Geosciences Union. 


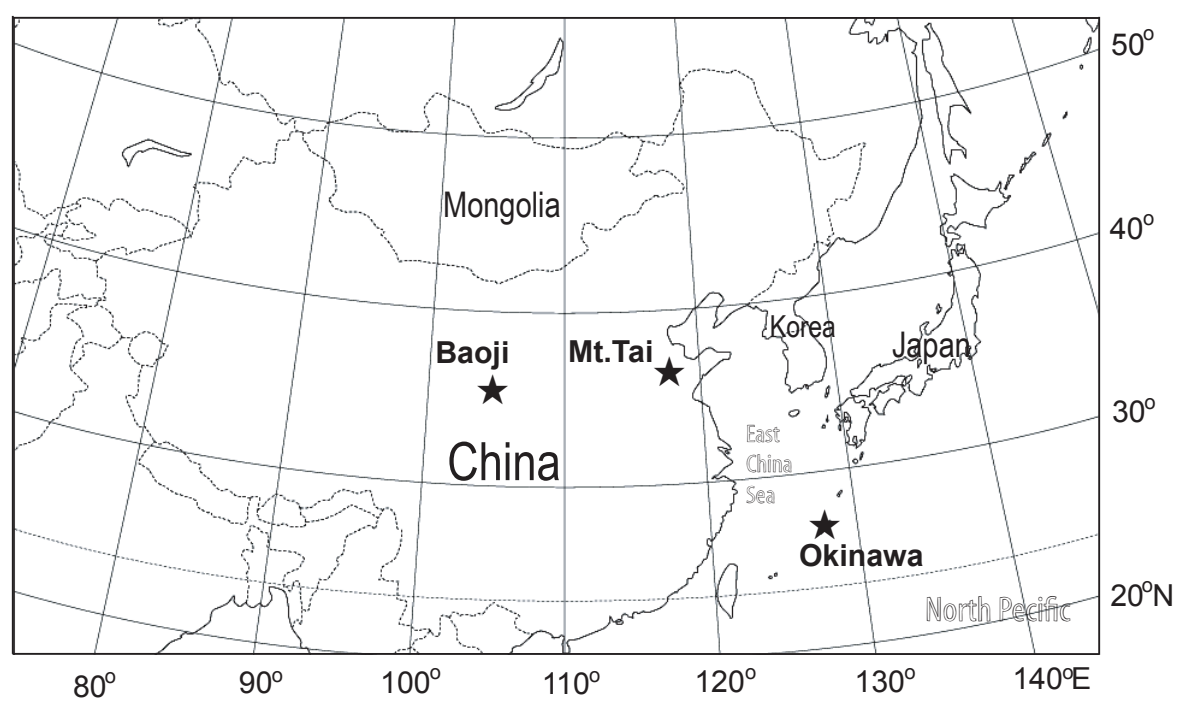

Fig. 1. A map showing locations of the sampling sites and their surroundings in East Asia.

cases, adding more absorbing soot and organic aerosol to the Asian and Pacific atmosphere (Aldhous, 2005; Arimoto et al., 2006). Economic expansion in China causes an increase in the amount of $\mathrm{SO}_{2}$, organic matter, and soot emitted into the East Asia atmosphere (Akimoto, 2003; Huebert et al., 2003). The frequent presence of desert dust makes the East Asian atmosphere more complex by scattering sunlight back to space and absorbing solar and terrestrial radiation (Huebert et al., 2003). Moreover, the dust also serves as an alkaline surface for the uptake of acidic gases. Intense industrialization and urbanization in China result in the atmospheric level of nitrogen dioxide higher than those in Europe and North America (Akimoto, 2003), thus the oxidizing environment of the East Asian atmosphere is likely being changed.

Physical properties of atmospheric aerosols depend on their chemical compositions and sizes (Seinfeld and Pandis, 1998; Hinds, 1999; Kanakidou et al., 2005). These airborne particles cover a wide range of sizes from a few nanometers to several hundreds of micrometers, commonly a hundredfold range between the smallest and the largest particles of an aerosol (Seinfeld and Pandis, 1998; Finlayson-Pitts and Pitts Jr, 2000). Numerous studies have demonstrated that chemical and physical properties of atmospheric aerosols including concentrations, compositions and size distributions are areaand location-specific (Pierce and Katz, 1975; Venkataraman et al., 1994, 2002; Kleeman and Cass, 1999; Kleeman et al., 1999, 2008; Riddle et al., 2008). Few studies on size distributions of organic aerosols were sparsely conducted for $n$-alkanes, PAHs and carboxylic acids in economically developed coastal cities in China such as Hong Kong (Yu et al., 2004; Huang et al., 2006; Zheng et al., 2008), Guangzhou (Bi et al., 2005; Duan et al., 2007) and Beijing (Yao et al., 2003). However, there is no such a study from inland regions of the country.
In order to investigate the similarity and differences in the chemical compositions and size distributions of aerosols from different atmospheric environments in East Asia, we have characterized size-segregated atmospheric particles from Baoji (an inland Chinese city), Mt. Tai (China) and Okinawa Island (Japan). In the current paper we first present concentrations, compositions, and sources of particulate organic compounds (i.e. $n$-alkanes, PAHs and hopanes) in the three types of atmospheric environments, and then characterize their detailed size distributions on a molecular level.

\section{Experimental section}

\subsection{Sample collection}

Baoji is a mid-scale city located in central China with a population of 0.75 million (Fig. 1). The sampler was set on the rooftop of a three-floor building at the Environment Monitoring Station of Baoji, which is in the urban center. Winter sampling was performed on 11-14 January and 1220 February 2008, while spring sampling was conducted on 12-24 April 2008. Size- segregated mountain aerosols were collected on the mountaintop (elevation of $1534 \mathrm{~m}$ a.s.l.) of Mt. Tai located in the central North China Plain, which faces to the East China Sea, Korean Peninsula and Japanese Islands. The mountain sampling was performed for 7 days (22-29 June 2006) in the summer and 12 days (12-24 January 2008) in the winter on the square in front of the Meteorological Station located on the mountaintop. Sizesegregated marine aerosols were collected from 18 March to 12 April 2008 at Cape Hedo of Okinawa Island, Japan (Fig. 1). There is no major industry on the island, and local 
Table 1. Sampling information and particle concentrations.

\begin{tabular}{lccccc}
\hline & \multicolumn{2}{c}{ Urban (Baoji) } & \multicolumn{2}{c}{ Mountain (Mt. Tai) } & Marine (Okinawa Is.) \\
& Winter & Spring & Winter & Summer & Spring \\
\hline Date & $1 / 11-14$ & $4 / 12-24$ & $1 / 12-24$ & $6 / 22-28$ & $3 / 18-4 / 12$ \\
& $2 / 12-20$ & 2008 & 2008 & 2006 & 2008 \\
& 2008 & & & & \\
Duration of each sampling & 4 days & 4 days & 4 days & 7 days & $3-5$ days \\
Number of sample sets & 3 & 3 & 3 & 1 & 5 \\
$\mathrm{TSP}^{\mathrm{a}}, \mu \mathrm{g} \mathrm{m}^{-3}$ & $316 \pm 76$ & $286 \pm 150$ & $102 \pm 60$ & $116^{\mathrm{b}}$ & Not determined \\
\hline
\end{tabular}

\footnotetext{
a a total suspended particles.

${ }^{\mathrm{b}}$ particles with aerodynamic diameter less than $9.0 \mu \mathrm{m}$.
}

anthropogenic activities are insignificant. Thus air pollution from the local sources is negligible.

Size-segregated aerosols at the urban and mountain sites were collected by Andersen 8-stage air samplers (Thermoelectronic Company, USA) with the same cutoff sizes of 9.0, $5.8,4.7,3.3,2.1,1.1,0.7$, and $0.4 \mu \mathrm{m}$ at an airflow rate of $28.3 \mathrm{~L} \mathrm{~min}^{-1}$. On the other hand, the marine size-resolved aerosols were collected by another type of Andersen 8-stage sampler (Tokyo Dylec Company, Japan) at a flow rate of $100 \mathrm{~L} \mathrm{~min}^{-1}$ with cutoff sizes of 11.3, 7.0, 4.7, 3.3, 2.1, 1.1, 0.7 , and $0.4 \mu \mathrm{m}$. An old version of Andersen 8-stage sampler was used during the summer mountain sampling, which collected particles larger than $9 \mu \mathrm{m}$ by impacting the aerosols into a steel vessel. These particles were collected using a brush after sampling, and not analyzed due to the potential collection loss. After sampling all the samples were stored at $-20^{\circ} \mathrm{C}$ before analysis. Information including dates, sample numbers, sampling durations and particle concentrations is shown in Table 1.

\subsection{Sample extraction, derivatization and GC/MS analysis}

Detailed methods for extraction, derivatization and gas chromatography/mass spectrometer (GC/MS) analysis were described elsewhere (Wang et al., 2006). Briefly, aliquots of the sample and blank filters were extracted with a mixture of dichloromethane and methanol $(2: 1, \mathrm{v} / \mathrm{v})$ under ultrasonication. The extracts were concentrated using a rotary evaporator under vacuum and then dried under a pure nitrogen stream. After converting polar compounds into non-polar ones through a reaction with $\mathrm{N}, \mathrm{O}$ bis-(trimethylsilyl)trifluoroacetamide (BSTFA), the extracts were diluted with $n$-hexane prior to GC/MS determination.

GC/MS analysis of the derivatized fraction was performed using a Hewlett-Packard 6890 GC coupled to a HewlettPackard 5973 MSD. The GC separation was carried out on a DB-5MS fused silica capillary column with the GC oven temperature programmed from $50^{\circ} \mathrm{C}(2 \mathrm{~min})$ to $120^{\circ} \mathrm{C}$ at $15^{\circ} \mathrm{C} \mathrm{min}{ }^{-1}$ and then to $300^{\circ} \mathrm{C}$ at $5^{\circ} \mathrm{C} \mathrm{min}^{-1}$ with a final isothermal hold at $300^{\circ} \mathrm{C}$ for $16 \mathrm{~min}$. The sample was injected in a splitless mode at an injector temperature of $280^{\circ} \mathrm{C}$, and scanned from 50 to 650 Daltons using electron impact (EI) mode at $70 \mathrm{eV}$. GC/MS response factors were determined using authentic standards. Average recoveries of the target compounds were better than $80 \%$. No significant contamination was found in the blanks except for $\mathrm{C}_{16: 0}$ and $\mathrm{C}_{18: 0}$ fatty acids, which were less than $2 \%$ of those in samples. Data presented were corrected for the field blanks but not corrected for the recoveries. Here we report on the non-polar compounds (i.e. $n$-alkanes, PAHs and hopanes) to discuss the differences in their molecular compositions, sources and size distributions in the three types of atmospheres.

\section{Results and discussion}

\subsection{Concentrations and molecular compositions}

Concentrations of individual compounds in all the impactor stages are summed and average concentrations are shown in Table 2 as total suspended particle (TSP)-equivalent concentrations. The TSP-equivalent concentrations of the compounds determined in Baoji city are 1-2 orders of magnitude higher than those in the mountain samples and 2-3 orders of magnitude higher than those in the marine samples. Compared with those in Chinese mega-cities (Wang et al., 2006), concentrations of $n$-alkanes and PAHs in Baoji are comparable or even higher than those in heavily polluted mega-cities like Xi' an and Chongqing, suggesting that air pollution in mid-scale cities of China are also very severe.

\subsection{1 $n$-alkanes}

Homologues $\left(\mathrm{C}_{18}-\mathrm{C}_{36}\right)$ of $n$-alkanes were detected in the urban, mountain and marine aerosols with different concentration levels and molecular compositions (Table 2 and Fig. 2). In the urban samples, total $n$-alkanes in all the nine stages are $1698 \pm 568 \mathrm{ng} \mathrm{m}^{-3}$ in winter and $487 \pm 145 \mathrm{ng} \mathrm{m}^{-3}$ in spring with a major peak at $\mathrm{C}_{23} / \mathrm{C}_{25}$ and a minor peak at 


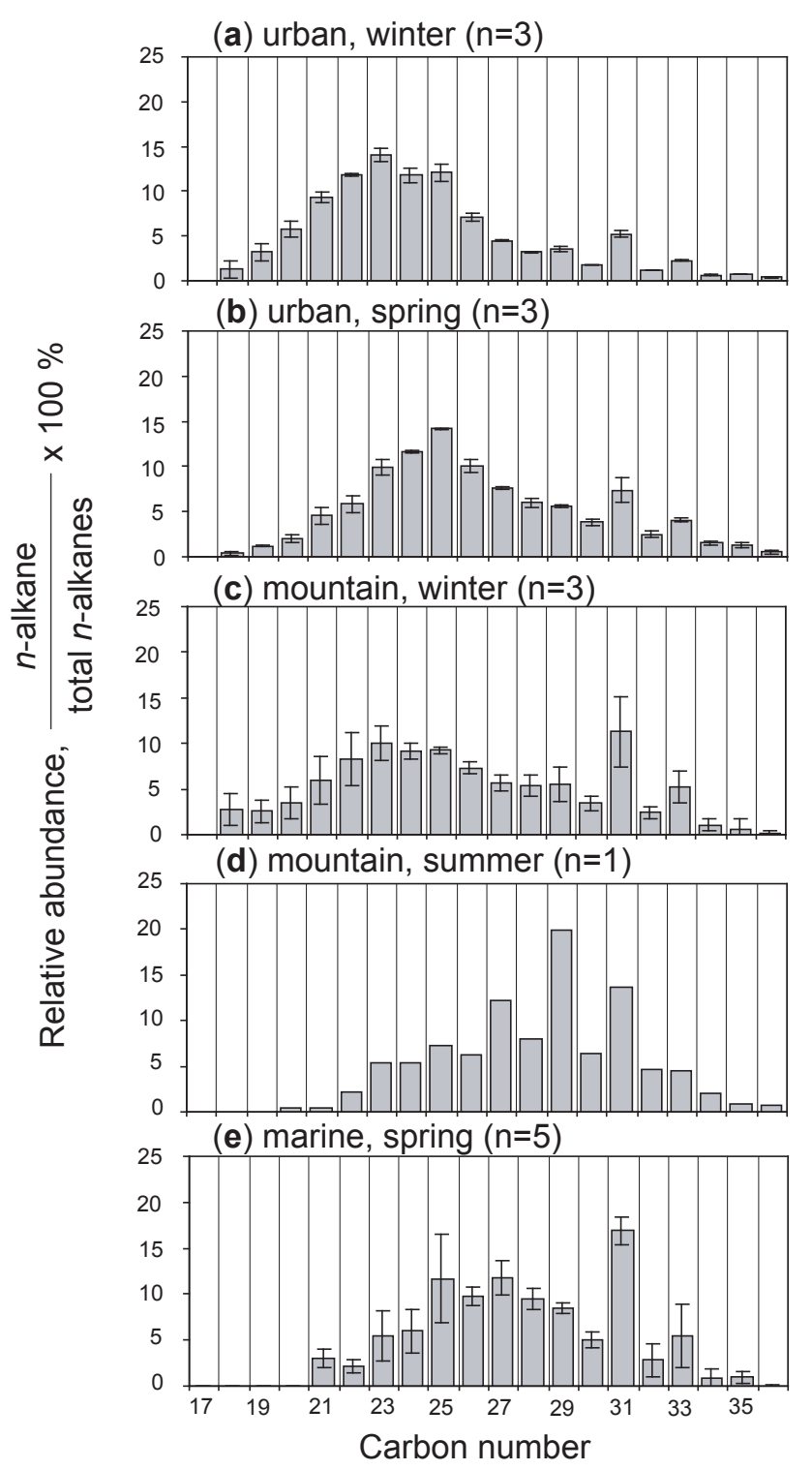

Fig. 2. Molecular distributions of ambient $n$-alkanes in particles from urban (a) and (b), TSP), mountain (c), TSP and (d), $\mathrm{PM}_{9}$ and marine (e), TSP atmospheres over East Asia during different seasons. (Error bar represents the standard deviation.)

$\mathrm{C}_{31}$ (Fig. 2a and b). In contrast, the total concentrations were found to be much lower in the mountain $\left(126 \pm 88 \mathrm{ng} \mathrm{m}^{-3}\right.$ in winter and $41 \mathrm{ng} \mathrm{m}^{-3}$ in summer) and marine atmospheres (7.9 $\pm 6.1 \mathrm{ng} \mathrm{m}^{-3}$ in spring) with a major peak at $\mathrm{C}_{29} / \mathrm{C}_{31}$ and a relatively minor predominance in a range of $\mathrm{C}_{23}-\mathrm{C}_{27}$ (Fig. 2c-e). $n$-Alkanes originated from plant wax are dominated by high molecular weight (HMW) ones $\left(>\mathrm{C}_{25}\right)$ (Hays et al., 2005), in contrast to $n$-alkanes derived from fossil fuel combustion, which are dominated by low molecular weight (LMW) ones $\left(\leq \mathrm{C}_{25}\right)$ (Rogge et al., 1993b; Simoneit et al., 2004a). Moreover, the natural $n$-alkanes have odd-number carbon predominance with a carbon preference index (CPI, odd/even) of $>5$, whereas CPI of the anthropogenic $n$-alkanes is close to unity (Rogge et al., 1993b; Simoneit et al., 2004a). As seen in Table 3, CPI values are close to unity for the urban and mountain samples in winter and spring, suggesting an importance of major contribution from anthropogenic activities such as domestic coal burning and petroleum combustion. The CPI values increased to around 2 for the mountain samples in summer and the marine samples in spring, indicating an enhanced biogenic input in those regions.

\subsubsection{PAHs}

In the urban area, TSP-equivalent concentrations of total PAHs were found to be $536 \pm 80 \mathrm{ng} \mathrm{m}^{-3}$ in winter and $161 \pm 39 \mathrm{ng} \mathrm{m}^{-3}$ in spring, which are 10 times higher than those of the mountain samples and 250 times higher than those of the marine samples (Table 2). Benzo(b/k)fluoranthene $(\mathrm{BbkF})$ is the dominant $\mathrm{PAH}$ in all the samples (Fig. 3 and Table 2), accounting for $17-62 \%$ of the total PAHs. The second most abundant PAH in the urban area is dibenzo(a,e)pyrene (DBP) (Fig. 3a and b), whose concentrations are $54 \pm 24$ and $19 \pm 6.5 \mathrm{ng} \mathrm{m}^{-3}$ during winter and spring, respectively. Conversely, the second most abundant PAH in the mountain and marine samples is fluoranthene (Flu) (Fig. 3c-e). Such a difference in the molecular composition of PAHs may be related to the differences in their sources and atmospheric processes (e.g. condensation and decomposition) during a long-range transport.

Diagnostic ratios of PAHs are indicative of their sources. For examples, concentration ratios of indeno(1,2,3cd)pyrene to benzo(ghi)perylene (IP/BghiP) are $0.2,0.5$ and 1.3 in the smokes from gasoline, diesel and coal combustions (Grimmer et al., 1983), whereas the ratios of benzo(ghi)perylene to benz(e)pyrene (BghiP/BeP) are 2.0 and 0.8 in the mobile exhausts and coal burning emissions, respectively (Grimmer et al., 1983; Ohura et al., 2004). As shown in Table 3, IP/BghiP and BghiP/BeP ratios in the urban, mountain and marine samples are close to those in coal burning smokes, suggesting that PAHs in the East Asia aerosols are largely derived from coal combustions, being consistent with the particulate PAHs compositions previously reported for 14 Chinese cities (Wang et al., 2006, 2007).

Table 4 shows the differences in the PAH compositions between the current study and those measured in US and $\mathrm{Eu}-$ rope. As mentioned above, $\mathrm{BbkF}(\mathrm{MW}=252)$ is the most abundant one among the major PAHs in the East Asia samples, in contrast to BghiP (MW=276), which is the most abundant species in US and Europe samples (see Table 4). BghiP/BeP ratio is 5.6 for Sacramento, 3.5 for Los Angeles, and 1.7 for London, respectively, indicating vehicle emissions as the major sources. Coal burning for house heating and cooking is still very common in China, especially 
Table 2. Ambient concentrations of organic compounds in the urban, mountain and marine atmospheres over East $\mathrm{Asia}^{\mathrm{n}} \mathrm{ng}^{-3}$.

\begin{tabular}{|c|c|c|c|c|c|}
\hline \multirow[b]{2}{*}{ Winter $(n=3)$} & \multicolumn{2}{|c|}{ Urban (Baoji) } & \multicolumn{2}{|c|}{ Mountain (Mt. Tai) } & \multirow[t]{2}{*}{ Marine (Okinawa Is.) } \\
\hline & Spring $(n=3)$ & Winter $(n=3)$ & Summer $^{\mathrm{a}}(\mathrm{n}=1)$ & Spring $(\mathrm{n}=5)$ & \\
\hline \multicolumn{6}{|l|}{ I. $n$-alkanes } \\
\hline Octadecane $\left(\mathrm{C}_{18}\right)$ & $18 \pm 8.9$ & $1.6 \pm 0.4$ & $2.4 \pm 0.6$ & $n d^{b}$ & nd \\
\hline Nonadecane $\left(\mathrm{C}_{19}\right)$ & $51 \pm 9.3$ & $5.6 \pm 1.4$ & $2.5 \pm 0.9$ & nd & nd \\
\hline Icosane $\left(\mathrm{C}_{20}\right)$ & $95 \pm 24$ & $9.4 \pm 1.2$ & $3.4 \pm 1.3$ & 0.2 & nd \\
\hline Henicosane $\left(\mathrm{C}_{21}\right)$ & $156 \pm 45$ & $21 \pm 3.8$ & $6.0 \pm 2.6$ & nd & $0.27 \pm 0.02$ \\
\hline Docosane $\left(\mathrm{C}_{22}\right)$ & $202 \pm 69$ & $28 \pm 5.2$ & $8.8 \pm 4.5$ & 0.9 & $0.16 \pm 0.12$ \\
\hline Tricosane $\left(\mathrm{C}_{23}\right)$ & $241 \pm 89$ & $48 \pm 12$ & $12 \pm 7.3$ & 2.2 & $0.38 \pm 0.29$ \\
\hline Tetracosane $\left(\mathrm{C}_{24}\right)$ & $203 \pm 78$ & $57 \pm 17$ & $11 \pm 7.8$ & 2.2 & $0.44 \pm 0.35$ \\
\hline Pentacosane $\left(\mathrm{C}_{25}\right)$ & $208 \pm 82$ & $69 \pm 21$ & $12 \pm 8.5$ & 3.0 & $0.82 \pm 0.63$ \\
\hline Hexacosane $\left(C_{26}\right)$ & $121 \pm 45$ & $50 \pm 17$ & $9.5 \pm 7.4$ & 2.6 & $0.79 \pm 0.65$ \\
\hline Heptacosane $\left(\mathrm{C}_{27}\right)$ & $77 \pm 28$ & $37 \pm 10$ & $7.7 \pm 6.0$ & 5.0 & $0.96 \pm 0.69$ \\
\hline Octacosane $\left(\mathrm{C}_{28}\right)$ & $54 \pm 18$ & $30 \pm 11$ & $7.4 \pm 6.0$ & 3.3 & $0.76 \pm 0.61$ \\
\hline Nonacosane $\left(\mathrm{C}_{29}\right)$ & $61 \pm 24$ & $27 \pm 7.5$ & $7.9 \pm 6.3$ & 8.2 & $0.69 \pm 0.53$ \\
\hline Triacotane $\left(\mathrm{C}_{30}\right)$ & $30 \pm 9.3$ & $19 \pm 7.0$ & $4.8 \pm 3.9$ & 2.6 & $0.42 \pm 0.32$ \\
\hline Hentriacotane $\left(\mathrm{C}_{31}\right)$ & $90 \pm 34$ & $37 \pm 16$ & $16 \pm 13$ & 5.6 & $1.4 \pm 1.0$ \\
\hline Dotriacotane $\left(\mathrm{C}_{32}\right)$ & $20 \pm 6.2$ & $13 \pm 4.9$ & $3.4 \pm 2.8$ & 1.9 & $0.26 \pm 0.19$ \\
\hline Tritriacotane $\left(\mathrm{C}_{33}\right)$ & $39 \pm 14$ & $20 \pm 6.2$ & $7.5 \pm 6.2$ & 1.9 & $0.50 \pm 0.36$ \\
\hline Tetratriacotane $\left(\mathrm{C}_{34}\right)$ & $11 \pm 4.0$ & $7.6 \pm 3.0$ & $1.8 \pm 1.8$ & 0.8 & $0.07 \pm 0.07$ \\
\hline Pentatriacotane $\left(\mathrm{C}_{35}\right)$ & $13 \pm 4.3$ & $6.3 \pm 2.8$ & $1.4 \pm 2.4$ & 0.4 & $0.06 \pm 0.07$ \\
\hline Hexatriacotane $\left(\mathrm{C}_{36}\right)$ & $6.6 \pm 3.2$ & $2.5 \pm 1.1$ & $0.3 \pm 0.6$ & 0.3 & nd \\
\hline Subtotal & $1698 \pm 568$ & $487 \pm 145$ & $126 \pm 88$ & 41 & $7.9 \pm 6.1$ \\
\hline \multicolumn{6}{|l|}{ II. PAHs } \\
\hline Dibenzothiophene (DB) & $2.3 \pm 0.8$ & $0.3 \pm 0.1$ & $1.1 \pm 0.7$ & nd & nd \\
\hline Phenanthrene (Phe) & $19 \pm 9.2$ & $1.4 \pm 0.7$ & $4.1 \pm 2.5$ & 0.5 & nd \\
\hline Anthracene (Ant) & $2.3 \pm 1.0$ & $0.4 \pm 0.3$ & $0.3 \pm 0.1$ & 0.1 & nd \\
\hline Fluoranthene (Flu) & $50 \pm 14$ & $6.0 \pm 2.0$ & $7.2 \pm 4.8$ & 1.1 & $0.13 \pm 0.10$ \\
\hline Pyrene (Pyr) & $39 \pm 9.4$ & $5.5 \pm 1.8$ & $4.5 \pm 2.8$ & 0.9 & $0.09 \pm 0.07$ \\
\hline Benzo(b)fluorene (BF) & $10 \pm 1.3$ & $0.7 \pm 0.5$ & $0.5 \pm 0.3$ & 0.1 & nd \\
\hline Chrysene/Triphenylene (CT) & $42 \pm 2.2$ & $13 \pm 5.2$ & $5.2 \pm 3.0$ & 0.2 & $0.06 \pm 0.06$ \\
\hline Benzo(b/k)fluoranthene (BbkF) & $112 \pm 11$ & $39 \pm 11$ & $14 \pm 8.8$ & 1.6 & $0.40 \pm 0.37$ \\
\hline Benzo(e)pyrene (BeP) & $29 \pm 2.5$ & $9.6 \pm 2.4$ & $3.1 \pm 2.3$ & 1.0 & $0.05 \pm 0.05$ \\
\hline Benzo(a)pyrene (BaP) & $33 \pm 2.9$ & $11 \pm 3.9$ & $2.1 \pm 1.4$ & 0.8 & $0.03 \pm 0.02$ \\
\hline Perylene (Per) & $8.3 \pm 1.0$ & $3.3 \pm 1.1$ & $0.3 \pm 0.2$ & 0.1 & nd \\
\hline Indeno[123-cd]pyrene (IP) & $39 \pm 4.6$ & $16 \pm 5.0$ & $2.4 \pm 1.9$ & 1.1 & $0.07 \pm 0.06$ \\
\hline Dibenz(a,h)anthracene (DBA) & $15 \pm 1.8$ & $2.9 \pm 0.7$ & $0.9 \pm 0.8$ & 0.2 & nd \\
\hline Benzo(ghi)perylene (BghiP) & $34 \pm 3.8$ & $15 \pm 4.3$ & $2.5 \pm 1.9$ & 1.0 & $0.05 \pm 0.04$ \\
\hline Anthanthrene (Antha) & $13 \pm 1.2$ & $4.0 \pm 1.8$ & $0.5 \pm 0.3$ & 0.1 & nd \\
\hline Coronene (Cor) & $34 \pm 9.9$ & $14 \pm 5.4$ & $3.0 \pm 2.5$ & 0.6 & $0.03 \pm 0.02$ \\
\hline Dibenzo(a,e)pyrene (DBP) & $54 \pm 24$ & $19 \pm 6.5$ & $6.3 \pm 5.9$ & nd & $0.03 \pm 0.03$ \\
\hline Subtotal & $536 \pm 80$ & $161 \pm 39$ & $58 \pm 42$ & 9.2 & $0.65 \pm 0.60$ \\
\hline \multicolumn{6}{|l|}{ III. Hopanes } \\
\hline $17 \alpha(\mathrm{H})-22,29,30$-trisnorhopane $\left(\mathrm{C}_{27 \alpha}\right)$ & $6.5 \pm 2.4$ & $1.3 \pm 0.2$ & $0.07 \pm 0.03$ & nd & nd \\
\hline $17 \beta(\mathrm{H})-22,29,30$-trisnorhopane $\left(\mathrm{C}_{27 \beta}\right)$ & $7.8 \pm 3.1$ & $1.5 \pm 0.1$ & $0.01 \pm 0.02$ & nd & nd \\
\hline $17 \alpha(\mathrm{H}), 21 \beta(\mathrm{H})-30$-norhopane $\left(\mathrm{C}_{29 \alpha \beta}\right)$ & $10 \pm 3.4$ & $3.7 \pm 0.4$ & $0.29 \pm 0.06$ & 0.05 & nd \\
\hline $17 \beta(\mathrm{H}), 21 \alpha(\mathrm{H})-30$-norhopane $\left(\mathrm{C}_{29 \beta \alpha}\right)$ & $13 \pm 5.3$ & $2.6 \pm 0.4$ & $0.10 \pm 0.09$ & nd & nd \\
\hline $17 \alpha(\mathrm{H}), 21 \beta(\mathrm{H})-30$-hopane $\left(\mathrm{C}_{30 \alpha \beta}\right)$ & $6.8 \pm 2.3$ & $3.6 \pm 0.4$ & $0.36 \pm 0.14$ & 0.11 & nd \\
\hline $17 \beta(\mathrm{H}), 21 \alpha(\mathrm{H})-30$-hopane $\left(\mathrm{C}_{30 \beta \alpha}\right)$ & $7.7 \pm 3.2$ & $1.8 \pm 0.2$ & $0.08 \pm 0.01$ & nd & nd \\
\hline $17 \alpha(\mathrm{H}), 21 \beta(\mathrm{H})$-22S-homohopane $\left(\mathrm{C}_{31 \alpha \beta} \mathrm{S}\right)$ & $1.6 \pm 0.5$ & $1.2 \pm 0.2$ & $0.06 \pm 0.01$ & 0.01 & nd \\
\hline $17 \alpha(\mathrm{H}), 21 \beta(\mathrm{H})-22 \mathrm{R}$-homohopane $\left(\mathrm{C}_{31 \alpha \beta} \mathrm{R}\right)$ & $3.3 \pm 1.3$ & $1.2 \pm 0.1$ & $0.07 \pm 0.06$ & 0.01 & nd \\
\hline $17 \beta(\mathrm{H}), 21 \alpha(\mathrm{H})$-30-homohopane $\left(\mathrm{C}_{31 \beta \alpha}\right)$ & $3.9 \pm 1.5$ & $0.9 \pm 0.1$ & $0.01 \pm 0.01$ & nd & nd \\
\hline $17 \alpha(\mathrm{H}), 21 \beta(\mathrm{H})-22 \mathrm{~S}$-bishomohopane $\left(\mathrm{C}_{32 \alpha \beta} \mathrm{S}\right)$ & $1.2 \pm 0.3$ & $1.1 \pm 0.2$ & $0.03 \pm 0.04$ & 0.03 & nd \\
\hline $17 \alpha(\mathrm{H}), 21 \beta(\mathrm{H})$-22R-bishomohopane $\left(\mathrm{C}_{32 \alpha \beta} \mathrm{R}\right)$ & $2.6 \pm 0.7$ & $1.1 \pm 0.1$ & $0.01 \pm 0.01$ & nd & nd \\
\hline Subtotal & $65 \pm 24$ & $20 \pm 2.4$ & $1.1 \pm 0.1$ & 0.21 & nd \\
\hline
\end{tabular}

a Sum of compounds in particles with a diameter less than $9.0 \mu \mathrm{m}$.

b Not detected. 


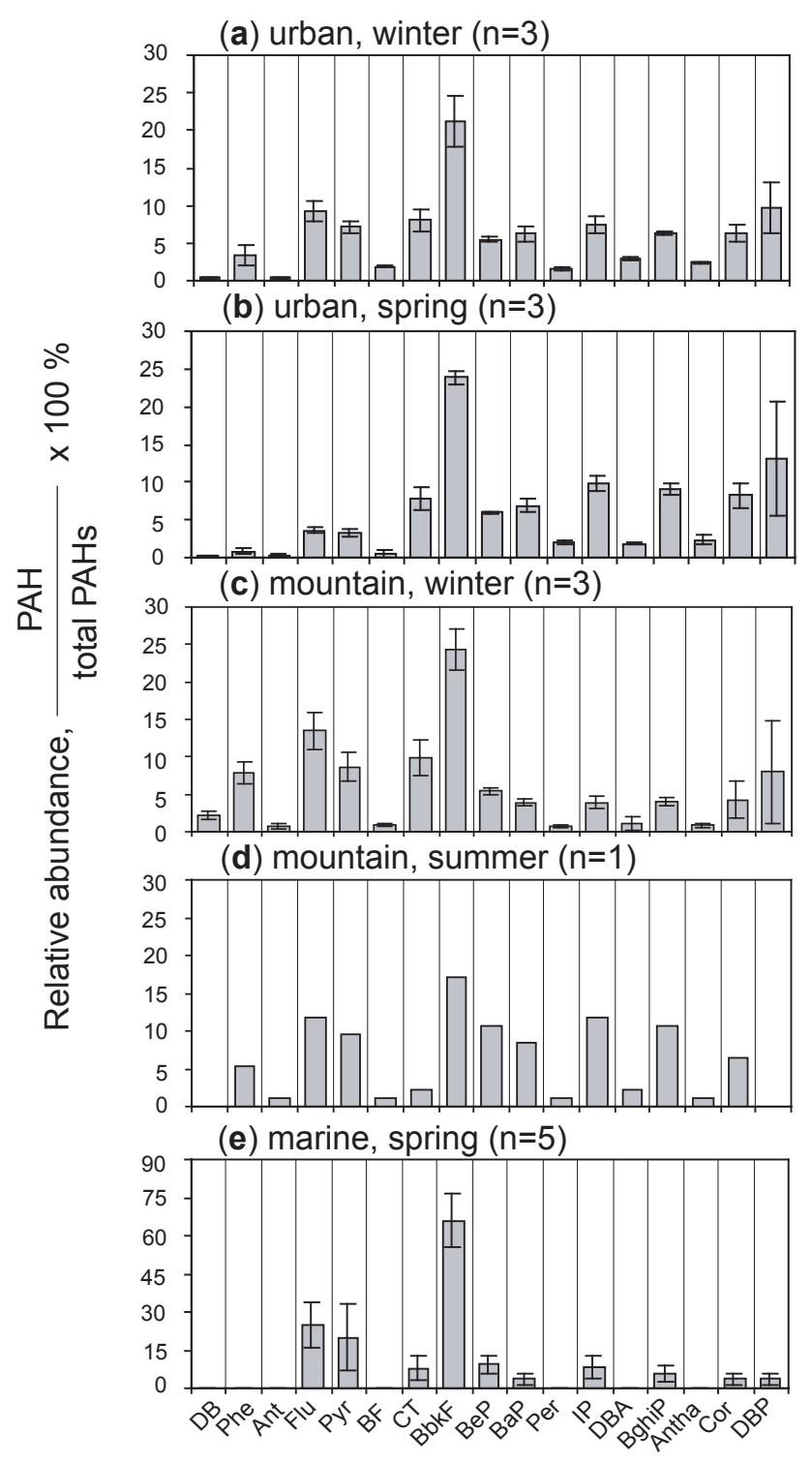

Fig. 3. Molecualr distributions of ambient PAHs in particles from urban (a) and (b), TSP, mountain (c), TSP and (d), $\mathrm{PM}_{9}$ and marine (e), TSP) atmospheres over East Asia during different seasons. (Error bar represents the standard deviation. Compound abbreviations shown in Table 2.)

in rural area, emitting more BbkF due to low combustion efficiency, because higher molecular weight PAHs like BghiP are formed under a higher temperature condition. Our results demonstrate that coal burning is still the major source of PAHs in China although the number of mobile vehicles has increased sharply in the recent years.

\subsubsection{Hopanes}

Hopanes are triterpenoid hydrocarbons that are primarily derived from bacteria as bacteriohopanols and produced by diagenesis in sediments over a geological time (Oros and Simoneit, 1999). They are abundant in coal and crude oils and enriched in lubricant oil fraction (Kawamura et al., 1995). A series of hopanes were detected in the urban samples with total concentrations of $65 \pm 24$ and $20 \pm 2.4 \mathrm{ng} \mathrm{m}^{-3}$ in winter and spring, respectively (Table 2). Concentrations of hopanes in the mountain samples are about two orders of magnitude lower than those in the urban Baoji samples, while hopanes in the marine samples are undetectable. Molecular composition of hopanes in the urban aerosols are characterized by one peak at $17 \beta(\mathrm{H}), 21 \alpha(\mathrm{H})$-30-norhopane $\left(\mathrm{C}_{29 \beta \alpha}\right)$ in winter and two peaks at $17 \alpha(\mathrm{H}), 21 \beta(\mathrm{H})$-30-norhopane $\left(\mathrm{C}_{29 \alpha \beta}\right)$ and $17 \alpha(\mathrm{H}), 21 \beta(\mathrm{H})-30$-hopane $\left(\mathrm{C}_{30 \alpha \beta}\right)$ in spring (Fig. 4a and b). Their dominations are different from those of the mountaintop samples, which are dominated by two major congeners $\left(\mathrm{C}_{29 \alpha \beta}\right.$ and $\left.\mathrm{C}_{30 \alpha \beta}\right)$ in winter and one major congener $\left(\mathrm{C}_{30 \alpha \beta}\right)$ in summer (Fig. $4 \mathrm{c}$ and $\left.\mathrm{d}\right)$.

Such differences in the molecular compositions of hopanes can be further assessed by their mass ratios. As shown in Table 3, diagnostic ratios of hopanes in the urban samples in winter fall in the range of coal burning emissions but shift toward the range of traffic emissions in spring when domestic coal burning for house heating is shut down. With respect to the mountain samples, we also found that hopane diagnostic ratios are more indicative of coal burning smoke in winter than in summer. However, the wintertime ratios in the mountain samples are less indicative of coal combustion emissions compared to those in the urban samples. Mt. Tai is located in the east coastal China, where economy is more developed than that in inland cities like Baoji and traffic pollution is much more significant (Akimoto, 2003; Wang et al., 2007). Thus contributions of mobile emissions to hopanes are pronounced in the mountain region especially in summer (Table 3), being consistent with a previous study for Nanjing, a city located in eastern China (Wang et al., 2007, 2009).

\subsection{Size distributions}

Concentrations of the three classes of compounds in each impactor stage are presented in Table 5, together with their cumulative percentages calculated. Wintertime cumulative percentages of $n$-alkanes (86\%, Table 5), PAHs (93\%) and hopanes $(90 \%)$ in the urban fine particles $(<2.1 \mu \mathrm{m})$ are higher than those $(80 \%, 85 \%$ and $82 \%$ for $n$-alkanes, PAHs and hopanes, respectively, Table 5) in the mountain fine particles. Further, their springtime cumulative percentages $(77 \%$ and $94 \%$ for $n$-alkanes and PAHs, Table 5) in the urban (Baoji) fine particles are also higher than those $(65 \%$ and $87 \%$ for $n$-alkanes and PAHs) in the marine fine particles, suggesting that compared to those in the mountain and marine samples $n$-alkanes, PAHs and hopanes are enriched in smaller particles in the urban air. Detailed differences in their size distributions among the three types of samples are further discussed below. 
Table 3. TSP-equivalent concentrations $\left(\mathrm{ng} \mathrm{m}^{-3}\right)$ of biomarkers and their diagnostic ratios.

\begin{tabular}{|c|c|c|c|c|c|c|c|c|}
\hline & \multicolumn{2}{|c|}{ Urban } & \multicolumn{2}{|c|}{ Mountain } & \multirow{2}{*}{$\begin{array}{r}\text { Marine } \\
\text { spring } \\
(n=5)\end{array}$} & \multicolumn{3}{|c|}{ Sources } \\
\hline & $\begin{array}{r}\text { winter } \\
(n=3)\end{array}$ & $\begin{array}{l}\text { spring } \\
(\mathrm{n}=3)\end{array}$ & $\begin{array}{r}\text { winter } \\
(n=3)\end{array}$ & $\begin{array}{r}\text { summer }^{\mathrm{a}} \\
\quad(\mathrm{n}=1)\end{array}$ & & gasoline & diesel & coal \\
\hline \multicolumn{9}{|l|}{ I. $n$-alkanes } \\
\hline Plant wax ${ }^{b}$ & $228 \pm 87$ & $74 \pm 21$ & $25 \pm 18$ & 13 & $2.3 \pm 1.7$ & & & \\
\hline Fossil fuel ${ }^{b}$ & $1470 \pm 482$ & $413 \pm 124$ & $101 \pm 71$ & 28 & $5.6 \pm 4.2$ & & & \\
\hline WNA $\%^{\mathrm{c}}$ & $13 \pm 1.0$ & $15 \pm 0.2$ & $19 \pm 4.0$ & 31 & $30 \pm 4.3$ & & & \\
\hline $\mathrm{CPI}^{\mathrm{d}}$ & $1.2 \pm 0.0$ & $1.3 \pm 0.0$ & $1.3 \pm 0.2$ & 1.8 & $1.7 \pm 0.2$ & & & \\
\hline \multicolumn{9}{|l|}{ II. PAHs } \\
\hline $\mathrm{BeP} /(\mathrm{BeP}+\mathrm{BaP})$ & $0.5 \pm 0.0$ & $0.5 \pm 0.0$ & $0.6 \pm 0.0$ & 0.6 & $0.6 \pm 0.0$ & & & \\
\hline IP/BghiP & $1.2 \pm 0.1$ & $1.1 \pm 0.3$ & $1.9 \pm 0.1$ & 1.0 & $1.4 \pm 0.1$ & $0.2^{\mathrm{e}}$ & $0.5^{\mathrm{e}}$ & $1.3^{\mathrm{e}}$ \\
\hline BghiP/BeP & $1.2 \pm 0.0$ & $1.5 \pm 0.1$ & $0.8 \pm 0.2$ & 1.0 & $0.9 \pm 0.1$ & $2.0^{\mathrm{f}}$ & & $0.8^{\mathrm{f}}$ \\
\hline \multicolumn{9}{|l|}{ III. Hopanes } \\
\hline $\mathrm{C}_{29 \alpha \beta} / \mathrm{C}_{30 \alpha \beta}$ & $1.5 \pm 0.0$ & $1.0 \pm 0.0$ & $0.9 \pm 0.2$ & 0.5 & & $0.6-0.7^{\mathrm{g}}$ & $0.4^{\mathrm{g}}$ & $0.6-2.0^{\mathrm{h}}$ \\
\hline $\mathrm{C}_{31 \alpha \beta}[\mathrm{S} / \mathrm{S}+\mathrm{R}]$ & $0.3 \pm 0.0$ & $0.5 \pm 0.0$ & $0.5 \pm 0.2$ & 0.6 & & $0.6^{\mathrm{g}}$ & $0.5^{\mathrm{g}}$ & $0.1-0.4^{\mathrm{h}}$ \\
\hline $\mathrm{C}_{32 \alpha \beta}[\mathrm{S} / \mathrm{S}+\mathrm{R}]$ & $0.3 \pm 0.0$ & $0.5 \pm 0.0$ & & & & $0.6^{\mathrm{g}}$ & $0.6^{\mathrm{g}}$ & $0.2-0.4^{\mathrm{h}}$ \\
\hline
\end{tabular}

a Aerosols with $\mathrm{Dp}<9.0 \mu \mathrm{m}$

b Plant wax $n$-alkanes: calculated as the excess odd homologues-adjacent even homologues average and the difference from the total $n$ alkanes is the fossil fuel-derived amount (Simoneit et al., 1991, 2004b)

c WNA \%: wax $n$-alkanes percentage, calculated as $\sum \mathrm{Cn}-0.5\left(\mathrm{C}_{\mathrm{n}-1}+\mathrm{C}_{\mathrm{n}+1}\right) / \sum n$-alkanes (Simoneit et al., 1991; Kavouras and Stephanou, 2002)

${ }^{\mathrm{d}} \mathrm{CPI}$, carbon preference index, $\mathrm{CPI}_{1}=\sum \mathrm{C}_{19}-\mathrm{C}_{35} / \sum \mathrm{C}_{18}-\mathrm{C}_{34}$

e (Grimmer et al., 1983)

$\mathrm{f}$ (Ohura et al., 2004)

g (Rogge et al., 1993a)

h (Oros and Simoneit, 2000).

Table 4. Comparison of compositions of major PAHs with those measured in US and Europe.

\begin{tabular}{|c|c|c|c|c|c|c|c|}
\hline Location & $\begin{array}{l}\text { Site } \\
\text { description }\end{array}$ & $\begin{array}{l}\text { Particle } \\
\text { size }\end{array}$ & Season & $\mathrm{BbkF} / \mathrm{BeP}$ & $\mathrm{IP} / \mathrm{BeP}$ & BghiP/BeP & References \\
\hline \multicolumn{8}{|l|}{ I. East Asia } \\
\hline \multirow[t]{2}{*}{ Baoji, China } & \multirow[t]{2}{*}{ Urban } & TSP & Winter & $3.8 \pm 0.4$ & $1.3 \pm 0.1$ & $1.2 \pm 0.0$ & This study \\
\hline & & TSP & Spring & $4.0 \pm 0.1$ & $1.7 \pm 0.2$ & $1.5 \pm 0.1$ & \\
\hline \multirow[t]{2}{*}{ Mt. Tai, China } & \multirow[t]{2}{*}{ Mountain } & TSP & Winter & $4.5 \pm 0.2$ & $0.7 \pm 0.2$ & $0.8 \pm 0.2$ & This study \\
\hline & & $\mathrm{PM}_{9}$ & Summer & 1.6 & 1.1 & 1.0 & \\
\hline Okinawa Is., Japan & Marine & TSP & Spring & $7.8 \pm 0.6$ & $1.3 \pm 0.1$ & $0.9 \pm 0.1$ & This study \\
\hline \multicolumn{8}{|l|}{ II. US and Europe } \\
\hline Sacramento, US & Urban & $\mathrm{PM}_{1.8}$ & Winter & 2.3 & 0.4 & 5.6 & Kleeman et al., 2008 \\
\hline Los Angeles, US & Urban & TSP & Annual & 1.0 & 1.3 & 3.5 & Finlayson-Pitts and Pitts Jr, 2000 \\
\hline London, UK & Urban & TSP & Autumn & 0.3 & 0.9 & 1.7 & Finlayson-Pitts and Pitts Jr, 2000 \\
\hline
\end{tabular}

\subsection{1 $n$-alkanes}

To better understand the differences in size distributions of $n$-alkanes from natural and anthropogenic sources, total $n$-alkanes in each impactor stage were differentiated as plant wax and fossil fuel derived $n$-alkanes using the method described by Simoneit et al. (2004a). Concentrations of the two classes of $n$-alkanes and CPI values of the total $n$-alkanes are plotted in Fig. 5 as a function of particle sizes.

In the urban atmosphere both fossil fuel derived and plant wax derived $n$-alkanes showed a unimodal size distribution in winter and spring with maximal concentrations at range 
Table 5. Concentrations of $n$-alkanes, PAHs and hopanes in each stage of the impactor samples from the urban, mountain and marine atmosphere over East Asia.

\begin{tabular}{|c|c|c|c|c|c|c|c|c|c|}
\hline & \multicolumn{9}{|c|}{ Size range $(\mu \mathrm{m})$} \\
\hline & $<0.4$ & $0.4-0.7$ & $0.7-1.1$ & $1.1-2.1$ & $2.1-3.3$ & $3.3-4.7$ & $4.7-5.8$ & $5.8-9.0$ & $>9.0$ \\
\hline \multicolumn{10}{|c|}{ Urban (Bao ji) } \\
\hline \multicolumn{10}{|l|}{ I. Winter $(n=3)$} \\
\hline$\sum n$-alkanes, $\mathrm{ng} \mathrm{m}^{-3}$ & 217 & 321 & 486 & 437 & 103 & 54 & 29 & 26 & 25 \\
\hline cumulative percentage, $\%$ & 13 & 32 & 60 & 86 & 92 & 95 & 97 & 99 & 100 \\
\hline$\sum \mathrm{PAHs}, \mathrm{ng} \mathrm{m}^{-3}$ & 51 & 106 & 186 & 157 & 20 & 7.2 & 3.4 & 3.2 & 2.9 \\
\hline cumulative percentage, $\%$ & 9.5 & 29 & 64 & 93 & 97 & 98 & 99 & 99 & 100 \\
\hline$\sum$ Hopanes, $\mathrm{ng} \mathrm{m}^{-3}$ & 9.2 & 13 & 20 & 15 & 2.7 & 1.5 & 0.7 & 0.9 & 0.9 \\
\hline $\begin{array}{l}\text { cumulative percentage, } \% \\
\text { II. Spring }(n=3)\end{array}$ & 14 & 35 & 66 & 90 & 94 & 96 & 97 & 99 & 100 \\
\hline$\sum n-$ alkanes, $\mathrm{ng} \mathrm{m}^{-3}$ & 81 & 105 & 117 & 74 & 30 & 23 & 14 & 21 & 23 \\
\hline cumulative percentage, $\%$ & 17 & 38 & 62 & 77 & 83 & 88 & 91 & 95 & 100 \\
\hline$\sum$ PAHs, $\mathrm{ng} \mathrm{m}^{-3}$ & 29 & 52 & 49 & 23 & 3.8 & 1.9 & 0.9 & 1.3 & 1.3 \\
\hline cumulative percentage, $\%$ & 18 & 50 & 80 & 94 & 97 & 98 & 98 & 99 & 100 \\
\hline$\sum$ Hopanes, $\mathrm{ng} \mathrm{m}^{-3}$ & 4.0 & 4.3 & 4.4 & 3.4 & 1.0 & 0.9 & 0.5 & 0.9 & 1.0 \\
\hline cumulative percentage, $\%$ & 20 & 41 & 63 & 80 & 84 & 89 & 91 & 95 & 100 \\
\hline \multicolumn{10}{|c|}{ Mountain (Mt. Tai) } \\
\hline \multicolumn{10}{|l|}{ I. Winter $(n=3)$} \\
\hline$\sum n$-alkanes, $\mathrm{ng} \mathrm{m}^{-3}$ & 9 & 14 & 32 & 45 & 12 & 5 & 3 & 3 & 3 \\
\hline cumulative percentage, $\%$ & 7 & 18 & 43 & 80 & 89 & 93 & 95 & 98 & 100 \\
\hline$\sum$ PAHs, $\mathrm{ng} \mathrm{m}^{-3}$ & 2 & 7 & 17 & 23 & 6 & 1 & 0.5 & 0.4 & 0.4 \\
\hline cumulative percentage, $\%$ & 3 & 16 & 45 & 85 & 95 & 98 & 99 & 99 & 100 \\
\hline$\sum$ Hopanes, $\mathrm{pg} \mathrm{m}^{-3}$ & 83 & 170 & 309 & 327 & 94 & 49 & 13 & 23 & 18 \\
\hline $\begin{array}{l}\text { cumulative percentage, } \% \\
\text { II. Summer }(n=1)\end{array}$ & 8 & 23 & 52 & 82 & 91 & 95 & 96 & 98 & 100 \\
\hline$\sum n$-alkanes, $\mathrm{ng} \mathrm{m}^{-3}$ & 2 & 8 & 12 & 8 & 2 & 2 & 2 & 4 & n.a. ${ }^{a}$ \\
\hline cumulative percentage, $\%$ & 5 & 26 & 55 & 75 & 80 & 86 & 91 & 100 & n.a. \\
\hline$\sum$ PAHs, $\mathrm{ng} \mathrm{m}^{-3}$ & 0.5 & 2 & 3 & 2 & 0.7 & 0.4 & 0.3 & 0.3 & n.a. \\
\hline cumulative percentage, $\%$ & 5.6 & 24 & 61 & 83 & 90 & 94 & 97 & 100 & n.a. \\
\hline$\sum$ Hopanes, $\mathrm{pg} \mathrm{m}^{-3}$ & 20 & 34 & 51 & 23 & 0 & 19 & 7 & 24 & n.a. \\
\hline cumulative percentage, $\%$ & 11 & 30 & 59 & 72 & 72 & 83 & 87 & 100 & n.a. \\
\hline \multicolumn{10}{|c|}{ Marine (Okinawa Is.) } \\
\hline I. Spring $(n=5)$ & & & & & & & & & \\
\hline$\sum n$-alkanes, $\mathrm{ng} \mathrm{m}^{-3}$ & 0.7 & 0.6 & 2 & 2 & 0.8 & 0.5 & 0.2 & 0.1 & 1 \\
\hline cumulative percentage, $\%$ & 8 & 15 & 39 & 65 & 75 & 82 & 84 & 86 & 100 \\
\hline$\sum$ PAHs, $\mathrm{pg} \mathrm{m}^{-3}$ & 23 & 38 & 209 & 292 & 68 & 14 & 3 & 2 & 0 \\
\hline cumulative percentage, $\%$ & 3.5 & 9.4 & 42 & 87 & 97 & 99 & 100 & 100 & 100 \\
\hline
\end{tabular}

a: not available. Size fractions $(>9.0 \mu \mathrm{m})$ of the mountain summer samples sets were not analyzed.

of $0.7-1.1 \mu \mathrm{m}$ (Fig. 5a and b). With respect to the mountain samples, the two classes of $n$-alkanes presented a unimodal size distribution in winter with concentration maxima at the sizes of $0.7-1.1 \mu \mathrm{m}$ and $1.1-2.1 \mu \mathrm{m}$, respectively (Fig. 5c). Although a bimodal size distribution was found for both types of $n$-alkanes in the mountain summer aerosols (Fig. 5d), the fossil fuel derived $n$-alkanes showed a major peak in the size of $0.7-1.1 \mu \mathrm{m}$ and a minor peak in the size of $4.7-5.8 \mu \mathrm{m}$ while the plant wax derived $n$-alkanes presented two equivalent peaks at the same size ranges. A bimodal distribution was observed for the two types of $n$-alkanes in the marine aerosols with a maximum in the submicrometer size of $0.7-1.1 \mu \mathrm{m}$, followed by a small peak in supermicrometer size of $>11.3 \mu \mathrm{m}$, but their mass concentrations in submicrometer size $(<1.1 \mu \mathrm{m})$ are less than those in the urban and mountain aerosol samples (Fig. 5e and Table 5).

CPI values are close to unity in the backup filters and generally increase with an increase of particle sizes for all samples (Fig. 5a-e), except for the wintertime urban samples (Fig. 5a), indicating a predominance of fossil fuel-derived 
(a) urban, winter $(\mathrm{n}=3)$

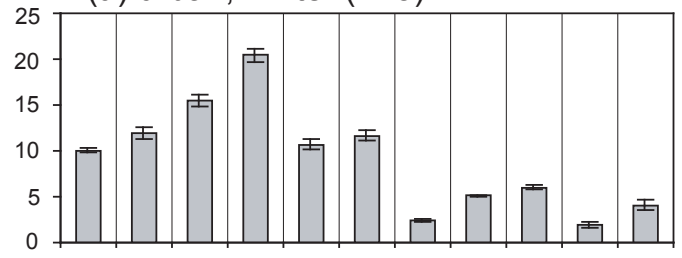

(b) urban, spring $(\mathrm{n}=3)$

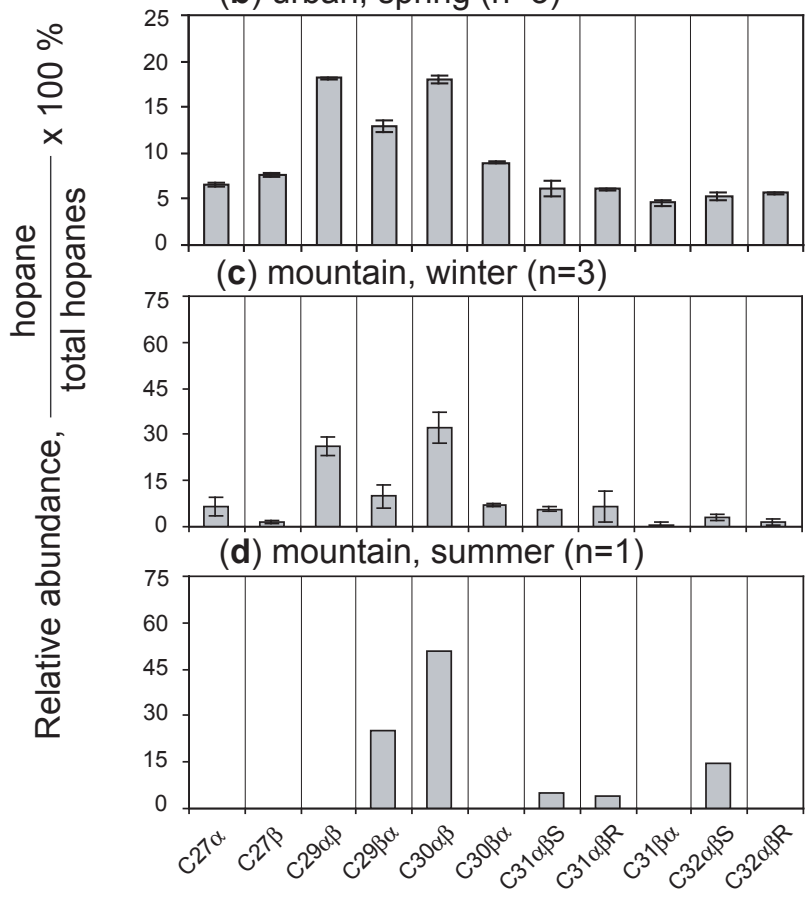

Fig. 4. Molecualr distributions of ambient hopanes in particles from urban (a) and (b), TSP and mountain (c), TSP and (d), $\mathrm{PM}_{9}$ atmospheres over East Asia during different seasons (Error bar represents the standard deviation. Compound abbreviations shown in Table 2.)

$n$-alkanes in the smallest size and an increasing input of plant wax derived $n$-alkanes along with an increase in particle sizes. The decreased CPI value in the winter urban aerosols $>3.3 \mu \mathrm{m}$ (Fig. 5a) was mostly caused by the decreased relative abundance of biogenic $n$-alkanes in the coarse fraction probably due to the deposition of large particles under the stagnant conditions.

\subsubsection{PAHs}

PAHs in all the samples were found with a unimodal distribution peaking in fine mode $(<2.1 \mu \mathrm{m})$ in the whole size ranges except for 3- and 4-ring PAHs in the summer mountain aerosols (Fig. 6a-e). In the urban aerosols, all the determined PAHs maximized at the range $0.7-1.1 \mu \mathrm{m}$ in winter and spring (Fig. 6a and b), but the second highest peak was found in a larger size $1.1-2.1 \mu \mathrm{m}$ during winter and in a smaller size $0.4-0.7 \mu \mathrm{m}$ during spring. In the mountain region, all the PAH concentrations maximized in the range $0.7-1.1 \mu \mathrm{m}$ or

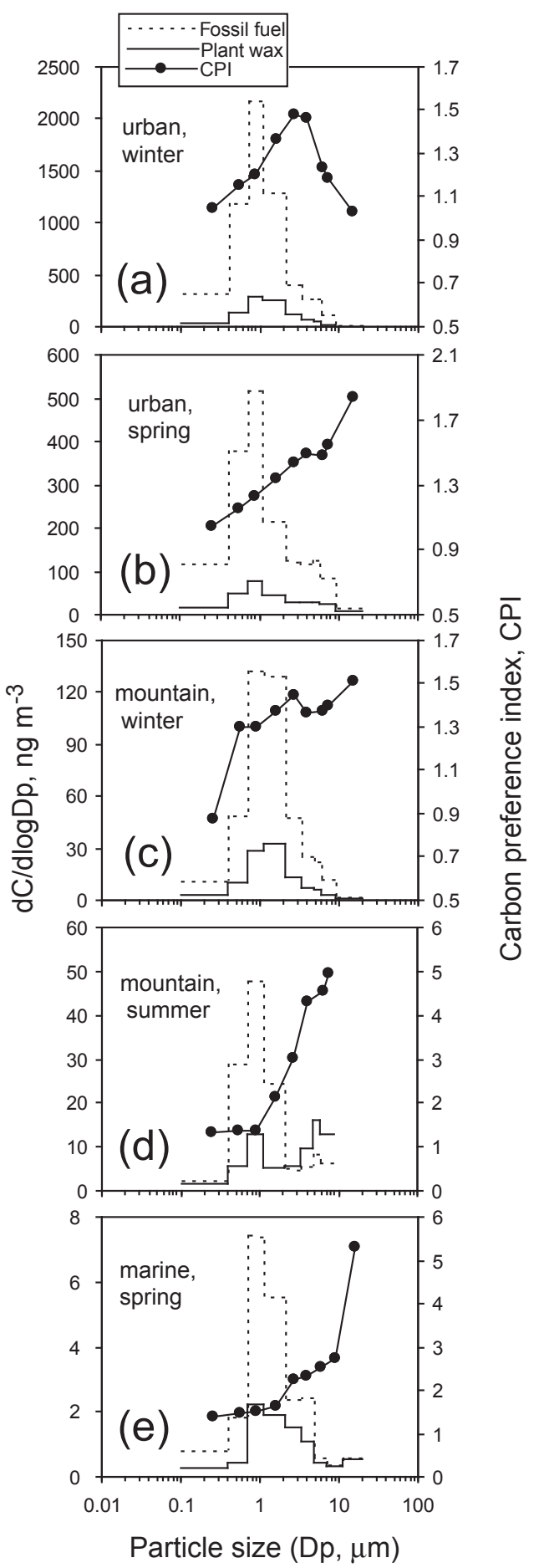

Fig. 5. Size distributions of fossil fuel- and plant wax- derived $n$-alkanes and CPI values of total $n$-alkanes in the urban, mountain and marine aerosols during different seasons. Plant wax derived $n$-alkanes are calculated as the excess odd carbon-numbered homologues-adjacent even carbon-numbered homologues average and the difference from the total $n$-alkanes is defined as the fossil fuel-derived $n$-alkanes (Simoneit et al., 1991, 2004b). 


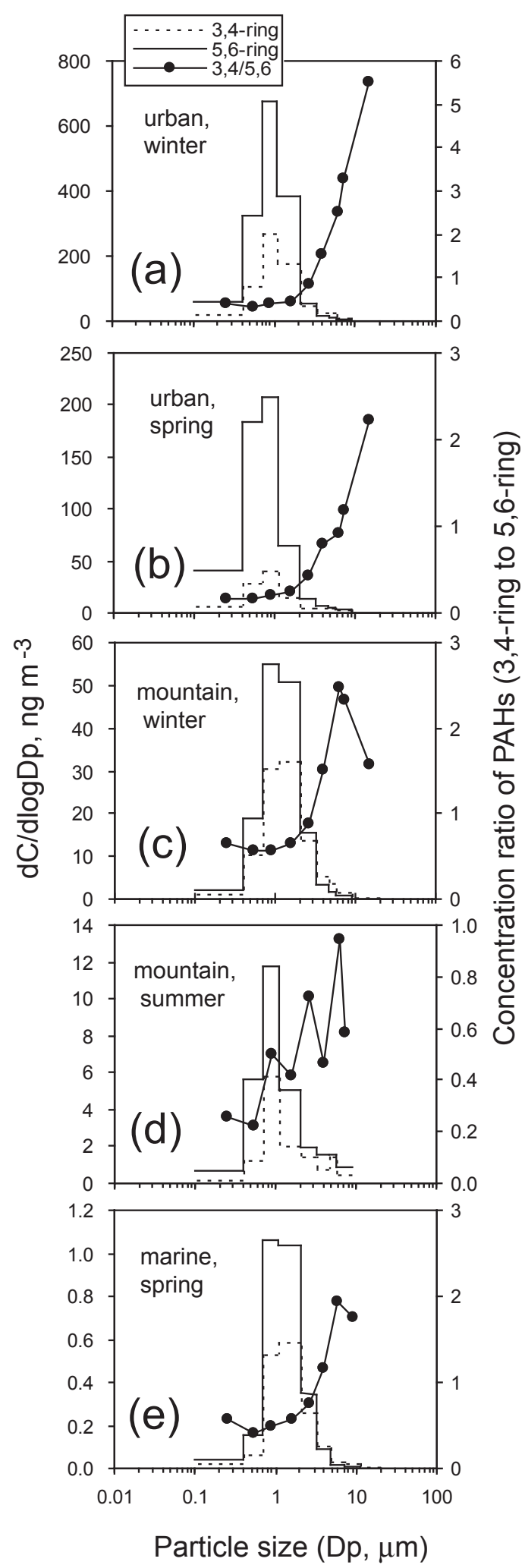

Fig. 6. Size distributions of PAHs in the urban, mountain and marine atmosphere during different seasons.
1.1-2.1 $\mu \mathrm{m}$ during winter and summer (Fig. $6 \mathrm{c}$ and d), but 3and 4-ring PAHs showed a minor peak at the size 4.7-5.8 $\mu \mathrm{m}$ during summer (Fig. 6d), probably caused by the enhanced adsorption of gaseous 3- and 4-ring PAHs on coarse particles in the hot season. As seen in Fig. 6e, all the PAHs in the marine aerosols showed two equivalent peaks in the sizes of $0.7-1.1$ and $1.1-2.1 \mu \mathrm{m}$, suggesting a significant migration toward larger particles compared to those in the urban atmosphere during the same season. In general, relative abundances of 3- and 4-ring PAHs to 5- and 6-ring PAHs are lower in small particles and higher in large particles in the three types of the atmospheres during different seasons (Fig. 6ae). Lower molecular weight (LMW) PAHs in solid phase can evaporate into the air and subsequently adsorb/condense onto pre-existing particles (Offenberg and Baker, 1999). Such a repartitioning effect can be further demonstrated by a difference between the concentration ratios of fluoranthene (Flu) and pyrene (Pyr) to that of benzo(ghi)perylene (BghiP) in each stage (Fig. 7a-d). Vapor pressure $\left(p=1.23 \times 10^{-3} \mathrm{~Pa}\right.$ at $25^{\circ} \mathrm{C}$ ) (Finlayson-Pitts and Pitts Jr, 2000) of Flu is larger than that $\left(p=6.0 \times 10^{-4} \mathrm{~Pa}\right)$ of Pyr, thus Flu migrates toward larger particles faster than does Pyr, leading to the difference between the ratios of Flu/BghiP and Pye/BghiP increasing as the increase of particle sizes (Fig. 7a-d).

\subsubsection{Hopanes}

$\mathrm{C}_{29 \alpha \beta}$ and $\mathrm{C}_{30 \alpha \beta}$ are the two major hopane species detected in the urban and mountain samples, which we select here to discuss the difference of size distributions of hopanes in the atmosphere during different seasons. The two hopanes showed a similar size distribution for the urban and mountain samples (Fig. 8a-d). This is reasonable because these congeners have common origins with similar molecular weight and are thus of similar behavior in the atmosphere. For the urban winter aerosols, they are characterized by a unimodal distribution with a peak in the $0.7-1.1 \mu \mathrm{m}$ size range (Fig. 8a). In contrast, they showed a bimodal distribution in spring with a major peak at size of $0.7-1.1 \mu \mathrm{m}$ and a minor peak at size of 3.3-4.7 $\mu \mathrm{m}$ (Fig. 8b). In the wintertime mountain samples, the two hopanes displayed a unimodal distribution with a maximum in the $0.7-1.1 \mu \mathrm{m}$ size (Fig. 8c), whereas they showed a bimodal distribution in summer with two peaks at the ranges of $0.7-1.1 \mu \mathrm{m}$ and $>3.3 \mu \mathrm{m}$ sizes (Fig. 8d), respectively.

\subsection{Geometric mean diameters (GMD) in the fine and coarse modes}

In order to better characterize the spatial and seasonal differences in size distributions of the determined organic compounds, we calculated their GMDs for the fine $(<2.1 \mu \mathrm{m})$ and coarse $(\geq 2.1 \mu \mathrm{m})$ modes and the whole range of impactor particle sizes (see Table 6). n-Akanes, PAHs and hopanes in all the samples mostly originated from fossil fuel 
Table 6. Geometric mean diameter $(\mathrm{GMD}, \mu \mathrm{m})^{\mathrm{a}}$ of the biomarkers calculated for the fine $(<2.1 \mu \mathrm{m})$ and coarse $(2.1 \mu \mathrm{m})$ particles and the whole range of impactor particle sizes (total) in the urban, mountain and marine atmospheres over East Asia.

\begin{tabular}{|c|c|c|c|c|c|c|c|c|c|c|c|c|c|c|c|}
\hline & \multicolumn{6}{|c|}{ Urban (Baoji) } & \multicolumn{6}{|c|}{ Mountain (Mt. Tai) } & \multicolumn{3}{|c|}{ Marine (Okinawa Is.) } \\
\hline & \multicolumn{3}{|c|}{ Winter $(n=3)$} & \multicolumn{3}{|c|}{ Spring (n=3) } & \multicolumn{3}{|c|}{ Winter $(n=3)$} & \multicolumn{3}{|c|}{ Summer $(\mathrm{n}=1)$} & \multicolumn{3}{|c|}{ Spring $(\mathrm{n}=5)$} \\
\hline & Fine & Coarse & Total & Fine & Coarse & Total & Fine & Coarse & Total & Fine & Coarse & Total & Fine & Coarse & Total \\
\hline I. Particles ParticlParticles & $0.93 \pm 0.04$ & $4.34 \pm 0.33$ & $1.47 \pm 0.07$ & $0.85 \pm 0.04$ & $4.73 \pm 0.22$ & $1.85 \pm 0.12$ & $0.82 \pm 0.12$ & $4.63 \pm 0.17$ & $1.70 \pm 0.08$ & 0.65 & 5.56 & 2.49 & $\mathrm{nd}^{\mathrm{b}}$ & nd & nd \\
\hline \multicolumn{16}{|l|}{ II. $n$-alkanes } \\
\hline$\sum n$-alkanes & $0.77 \pm 0.03$ & $3.67 \pm 0.14$ & $0.94 \pm 0.02$ & $0.64 \pm 0.02$ & $4.26 \pm 0.18$ & $0.94 \pm 0.10$ & $0.89 \pm 0.16$ & $3.83 \pm 0.46$ & $1.13 \pm 0.21$ & 0.82 & 4.87 & 1.28 & $0.91 \pm 0.09$ & $3.88 \pm 0.43$ & $1.28 \pm 0.07$ \\
\hline Fossil fuel $^{\mathrm{c}}$ & $0.76 \pm 0.03$ & $3.80 \pm 0.38$ & $0.91 \pm 0.02$ & $0.64 \pm 0.02$ & $4.22 \pm 0.16$ & $0.90 \pm 0.10$ & $0.89 \pm 0.16$ & $3.70 \pm 0.17$ & $1.11 \pm 0.23$ & 0.84 & 4.62 & 1.05 & $0.90 \pm 0.10$ & $3.85 \pm 0.50$ & $1.24 \pm 0.13$ \\
\hline Plant wax ${ }^{c}$ & $0.89 \pm 0.05$ & $3.54 \pm 0.08$ & $1.15 \pm 0.05$ & $0.69 \pm 0.02$ & $4.38 \pm 0.27$ & $1.16 \pm 0.13$ & $0.89 \pm 0.17$ & $3.91 \pm 0.68$ & $1.24 \pm 0.12$ & 0.75 & 5.03 & 1.98 & $0.93 \pm 0.08$ & $3.92 \pm 0.23$ & $1.41 \pm 0.15$ \\
\hline \multicolumn{16}{|l|}{ III. PAHs } \\
\hline$\sum \mathrm{PAHs}$ & $0.83 \pm 0.05$ & $3.47 \pm 0.18$ & $0.91 \pm 0.06$ & $0.63 \pm 0.06$ & $3.81 \pm 0.18$ & $0.69 \pm 0.08$ & $0.99 \pm 0.11$ & $3.26 \pm 0.17$ & $1.14 \pm 0.17$ & 0.85 & 3.93 & 1.10 & $1.20 \pm 0.16$ & $3.07 \pm 0.19$ & $1.35 \pm 0.09$ \\
\hline 3,4-ring & $0.86 \pm 0.03$ & $3.72 \pm 0.18$ & $1.01 \pm 0.05$ & $0.68 \pm 0.07$ & $4.14 \pm 0.16$ & $0.84 \pm 0.10$ & $1.01 \pm 0.09$ & $3.41 \pm 0.20$ & $1.23 \pm 0.17$ & 0.91 & 3.95 & 1.26 & $1.22 \pm 0.11$ & $3.22 \pm 0.25$ & $1.40 \pm 0.09$ \\
\hline 5,6-ring & $0.82 \pm 0.06$ & $3.19 \pm 0.20$ & $0.87 \pm 0.06$ & $0.62 \pm 0.06$ & $3.59 \pm 0.12$ & $0.66 \pm 0.07$ & $0.97 \pm 0.12$ & $2.98 \pm 0.08$ & $1.07 \pm 0.18$ & 0.82 & 3.91 & 1.03 & $1.18 \pm 0.22$ & $2.93 \pm 0.23$ & $1.34 \pm 0.15$ \\
\hline \multicolumn{16}{|l|}{ IV. Hopanes } \\
\hline$\sum$ Hopanes & $0.74 \pm 0.03$ & $3.70 \pm 0.33$ & $0.86 \pm 0.01$ & $0.62 \pm 0.03$ & $4.38 \pm 0.23$ & $0.85 \pm 0.04$ & $0.90 \pm 0.20$ & $3.37 \pm 0.32$ & $1.15 \pm 0.47$ & 0.69 & 5.58 & 1.25 & nd & nd & nd \\
\hline $\mathrm{C}_{29 \alpha \beta}$ & $0.74 \pm 0.03$ & $3.82 \pm 0.36$ & $0.88 \pm 0.01$ & $0.60 \pm 0.03$ & $4.49 \pm 0.22$ & $0.86 \pm 0.06$ & $0.82 \pm 0.20$ & $3.31 \pm 0.30$ & $1.14 \pm 0.49$ & 0.71 & 3.98 & 0.87 & nd & nd & nd \\
\hline $\mathrm{C}_{30 \alpha \beta}$ & $0.73 \pm 0.03$ & $3.99 \pm 0.37$ & $0.93 \pm 0.01$ & $0.60 \pm 0.02$ & $4.52 \pm 0.16$ & $0.92 \pm 0.07$ & $0.90 \pm 0.19$ & $3.50 \pm 0.48$ & $1.26 \pm 0.54$ & 0.67 & 5.53 & 1.28 & nd & nd & nd \\
\hline
\end{tabular}

${ }^{\text {a }} \log \mathrm{GMD}=\left(\sum \mathrm{C}_{i} \log \mathrm{Dp}_{i}\right) / \sum \mathrm{C}_{i}$, where $\mathrm{C}_{i}$ is the concentration of compound in size $i$ and $\mathrm{Dp}_{i}$ is the geometric mean particle diameter collected on stage $i$ (Hinds, 1999).

$\mathrm{b}$ Not detected.

c Plant wax means $n$-alkanes derived from plant wax, and fossil fuel means $n$-alkanes derived from fossil fuel emissions (for detailed calculations see Table 3).
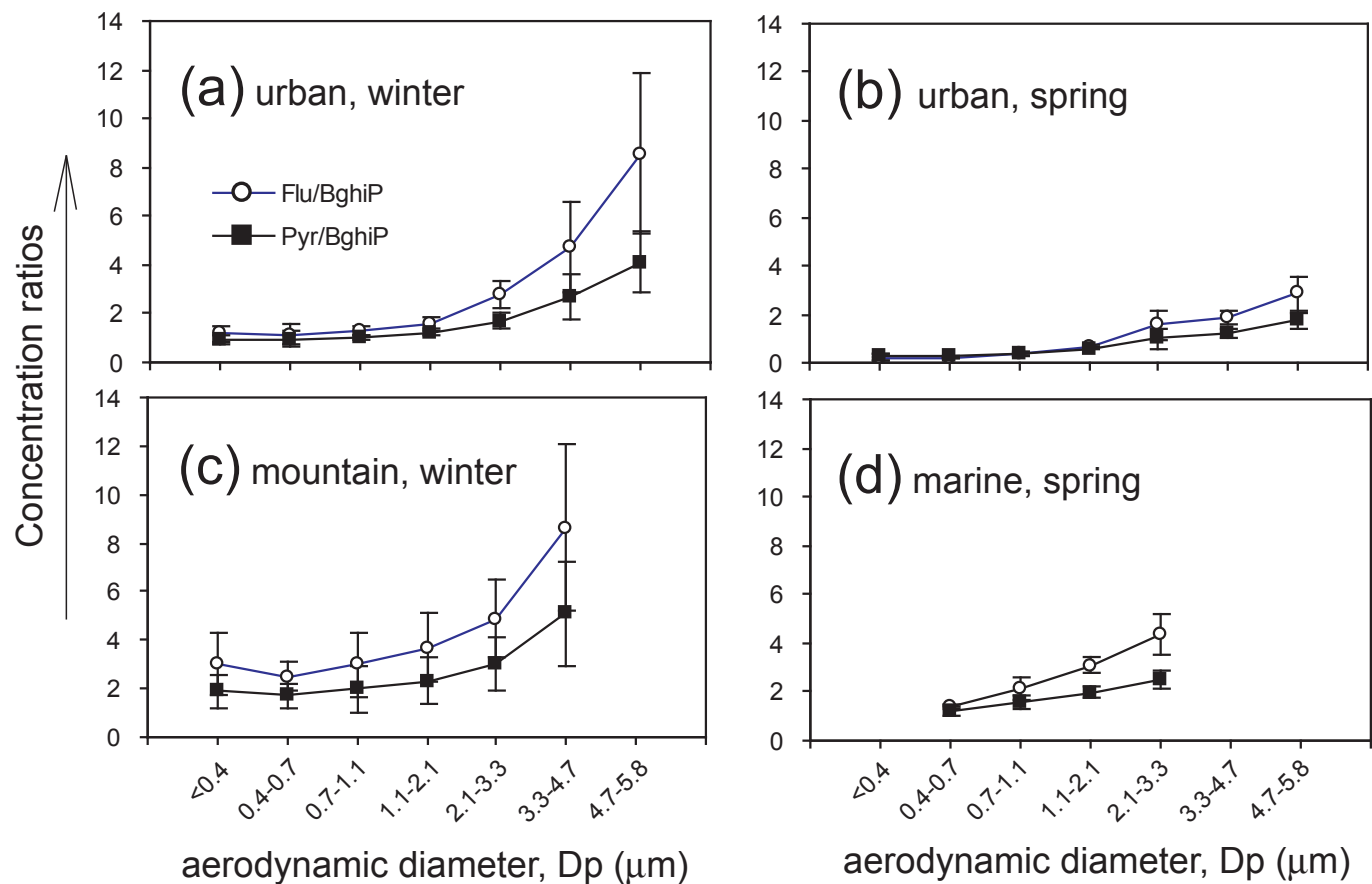

aerodynamic diameter, $\mathrm{Dp}(\mu \mathrm{m})$

Fig. 7. Relative concentration of fluoranthene (Flu) and pyrene (Pyr) to that of benzo(ghi)perylene (BghiP) in each stage at the urban, mountain and marine sites during the same season: (a) and (c) for winter and (b) and (d) for spring. (Data points are presented for the size ranges where BghiP can be detected. Error bar represents the standard deviation.)

combustions, and thus centered in fine particles (Keshtkar and Ashbaugh, 2007), leading to their total GMDs in the whole range of impactor sizes very close to the fine mode ones. Among the three sampling sites the fine and the total GMDs of all the compounds are smallest in the urban air and largest in the marine atmosphere, which is most likely due to the enhanced repartitioning and hygroscopic growth of organics during a long-range transport and the differences in their sources. In contrast, GMDs of fossil fuel-derived $n$-alkanes, PAHs and hopanes in coarse mode are largest in the urban area and smallest in the marine region, suggesting the increased deposition during the transport from the lowland region to the mountaintop and marine areas. However, wintertime GMDs (3.91 $\pm 0.68 \mu \mathrm{m}$, Table 5) of the plant 


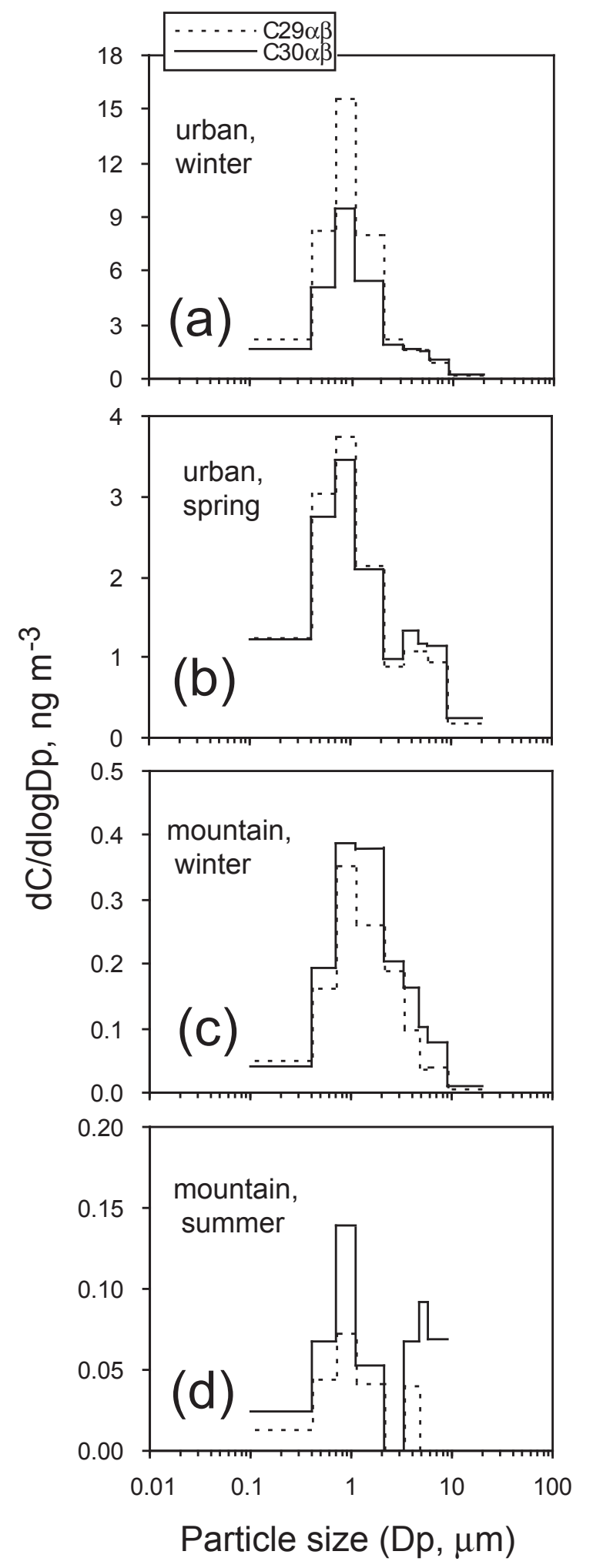

Fig. 8. Size distributions of hopanes $\left(\mathrm{C}_{29 \alpha \beta}\right.$ and $\left.\mathrm{C}_{30 \alpha \beta}\right)$ in the urban, mountain and marine atmosphere during different seasons. wax-derived $n$-alkanes in coarse mode in the mountain air are larger than those $(3.54 \pm 0.08 \mu \mathrm{m})$ in the urban atmosphere mainly due to an increased input by wind abrasion with local plant surface, while springtime GMDs $(3.92 \pm 0.23 \mu \mathrm{m}$, Table 6) of the plant wax-derived $n$-alkanes in coarse mode of the marine samples are smaller than those $(4.38 \pm 0.27 \mu \mathrm{m})$ of the urban samples mainly due to an enhanced deposition during a long range transport.

In the urban region, GMDs of all the compounds in fine mode are larger in winter than in spring, being opposite to those of the coarse mode (see Table 6 for the numbers). A similar trend was also found for the mountain samples between winter and summer seasons. Such seasonal variations can be explained by the differences in their sources and the enhanced effects of fine particle coagulation, organic compound repartitioning and coarse particle deposition in winter due to the inversion layer development (Herner et al., 2006). PAHs are produced by incomplete combustion of carbon-containing materials. Less volatile HMW PAHs are predominantly formed on smaller particles where they condense immediately after the emission of combustion products, while more volatile LMW PAHs are adsorbed on larger particles when the smoke is cooled down in the ambient air. Furthermore, solid-phase LMW PAHs can evaporate into the gas phase and re-adsorb/condense on pre-existing particles (Offenberg and Baker, 1999). Thus compared to HMW (5and 6-ring) PAHs, LMW (3- and 4-ring) PAHs showed larger GMDs for all the samples (Table 6). This repartitioning of semivolatile PAHs can be enhanced under higher ambient temperature, leading to an increase in the ratios of total GMDs of LMW PAHs to total GMDs of HMW PAHs in warm periods: a shift from 1.16 in winter to 1.27 in spring for the urban samples and from 1.15 in winter to 1.22 in summer for the mountaintop samples.

\section{Summary and conclusion}

$n$-Alkanes, PAHs and hopanes in size-segregated aerosols from the urban (Baoji), mountain (Mt. Tai) and marine (Okinawa Is.) sites over East Asia were determined on a molecular level for different seasons. Winter and spring concentrations of $n$-alkanes, PAHs and hopanes in the urban aerosols are $1698 \pm 568$ and $487 \pm 145 \mathrm{ng} \mathrm{m}^{-3}, 536 \pm 80$ and $161 \pm 39 \mathrm{ng} \mathrm{m}^{-3}$ and $65 \pm 24$ and $20 \pm 2.4 \mathrm{ng} \mathrm{m}^{-3}$, respectively. These values are 1-2 and 2-3 orders of magnitude higher than those of the mountain and marine aerosols, respectively. Concentration ratios and compositions of the organics indicate that coal combustion in China is the major source of airborne particulate PAHs over East Asia.

Size distributions of fossil fuel derived $n$-alkanes, PAHs and hopanes were generally found to be unimodal with a peak at the particle size less than $2.1 \mu \mathrm{m}$. In contrast, plant wax derived $n$-alkanes in the summer mountain and spring marine aerosols showed a bimodal size distribution with 
two peaks at the size ranges of $0.7-1.1 \mu \mathrm{m}$ and $>4.7 \mu \mathrm{m}$. Based on the calculation of the GMDs for the organic compounds, we found that fossil fuels derived $n$-alkanes, PAHs and hopanes in the urban aerosols are mostly presented in smaller sizes whereas those in the marine aerosols are mostly in larger sizes. Moreover, their sizes in fine mode are larger in winter than in spring and summer. Such spatial and seasonal differences are caused by the differences in their sources and the atmospheric processes such as the repartitioning of organic compounds and the coagulation and hygroscopic growth of aerosols during a long-range transport from the inland region to the marine area. Particle sizes of 3and 4-ring PAHs are larger than those of 5- and 6-ring PAHs for all the samples due to a repartitioning between gas-solid phases. Such an effect can be enhanced under a high temperature, causing the migration of LMW PAHs toward large particles more significant in summer than in winter.

Acknowledgements. We acknowledge M. Mochida and Nishita for the helps of aerosol sampling at Cape Hedo, Okinawa Island and National Institute of Environmental Studies, Japan and A. Takami for the courtesy of using the Cape Hedo Observatory Station for marine aerosol sampling. This work was financially supported by National Natural Science Foundation (No. 40873083) and the Knowledge Innovation Program of Chinese Academy Sciences (No. kzcx2-yw-148). This study was also supported in part by the Japanese Ministry of Education, Science and Culture through Gant-in-Aid No. 17340166. G. W. appreciates Japan Society for the Promotion of Science (JSPS) for the invitation fellowship (No. L08525).

Edited by: L. Molina

\section{References}

Akimoto, H.: Global air quality and pollution, Science, 302, 17161719, 2003.

Albrecht, B. A.: Aerosols, cloud microphysics, and fractional cloudiness, Science, 245, 1227-1230, 1989.

Aldhous, P.: China's burning ambition, Nature, 435, 1152-1154, 2005.

Anderson, H. R.: Air pollution and mortality: A history, Atmos. Environ., 43, 142-152, 2009.

Arimoto, R., Kim, Y. J., Kim, Y. P., Quinn, P. K., Bates, T. S., Anderson, T. L., Gong, S., Uno, I., Chin, M., Huebert, B. J., Clarke, A. D., Shinozuka, Y., Weber, R. J., Anderson, J. R., Guazzotti, S. A., Sullivan, R. C., Sodeman, D. A., Prather, K. A., and Sokolik, I. N.: Characterization of Asian Dust during ACE-Asia, Global Planet. Change, 52, 23-56, 2006.

Bi, X., Sheng, G., Peng, P., Chen, Y., and Fu, J.: Size distribution of $n$-alkanes and polycyclic aromatic hydrocarbons (PAHs) in urban and rural atmospheres of Guangzhou, China, Atmos. Environ., 39, 477-487, 2005.

Dockery, D. W., Pope, C. A., Xu, X., Spengler, J. D., Ware, J. H., Fay, M. E., Ferris Jr, B. G., and Speizer, F. E.: An association between air pollution and mortality in six US cities, New Engl. J. Med., 329, 1753-1759, 1993.
Duan, J. C., Bi, X. H., Tan, J. H., Sheng, G. Y., and Fu, J. M.: Seasonal variation on size distribution and concentration of PAHs in Guangzhou city, China, Chemosphere, 67, 614-622, 2007.

Finlayson-Pitts, B. J. and Pitts Jr, J. N.: Chemistry of the Upper and Lower Atmosphere, Academic Press, San Diego, 2000.

Grimmer, G., Jacob, J., and Noujack, K. W.: Profile of the polycyclic aromatic hydrocarbons from lubricating oils, Inventory by GC/MS-PAH in environmental materials, Part 1, Fresen. Z. Anal. Chem., 314, 13-19, 1983.

Herner, J. D., Ying, Q., Aw, J., Gao, O., Chang, D. P. Y., and Kleeman, M. J.: Dominant mechanism that shape the airborne particle size and composition distribution in central California, Aerosol Sci. Tech., 40, 827-844, 2006.

Hinds, W. C.: Aerosol Technology: Properties, Behavior, and Measurement of Airborne Particles, John Wiley and Sons, New York, 1999.

Huang, X. F., Yu, J. Z., He, L. Y., and Yuan, Z. B.: Watersoluble organic carbon and oxalate in aerosols at a coastal urban site in China: Size distribution characteristics, sources, and formation mechanisms, J. Geophys. Res.-Atmos., 111, D22212, doi:10.1029/2006JD007408, 2006.

Huebert, B. J., Bates, T., Russell, P. B., Shi, G. Y., Kim, Y. J., Kawamura, K., Carmichael, G., and Nakajima, T.: An overview of ACE-Asia: Strategies for quantifying the relationships between Asian aerosols and their climatic impacts, J. Geophys. Res.-Atmos., 108, 8663, doi:10.1029/2003JD003550, 2003.

Kanakidou, M., Seinfeld, J. H., Pandis, S. N., Barnes, I., Dentener, F. J., Facchini, M. C., Van Dingenen, R., Ervens, B., Nenes, A., Nielsen, C. J., Swietlicki, E., Putaud, J. P., Balkanski, Y., Fuzzi, S., Horth, J., Moortgat, G. K., Winterhalter, R., Myhre, C. E. L., Tsigaridis, K., Vignati, E., Stephanou, E. G., and Wilson, J.: Organic aerosol and global climate modelling: a review, Atmos. Chem. Phys., 5, 1053-1123, 2005,

http://www.atmos-chem-phys.net/5/1053/2005/.

Kavouras, I. G. and Stephanou, E. G.: Particle size distribution of organic primary and secondary aerosol constituents in urban, background marine, and forest atmosphere, J. Geophys. Res.Atmos., 107(D8), 4069, doi:10.1029/2000JD000278, 2002.

Keshtkar, H. and Ashbaugh, L. L.: Size distribution of polycyclic aromatic hydrocarbon particulate emission factors from agricultural burning, Atmos. Environ., 41, 2729-2739, 2007.

Kleeman, M. J. and Cass, G. R.: Effect of Emissions Control Strategies on the Size and Composition Distribution of Urban Particulate Air Pollution, Environ. Sci. Technol., 33, 177-189, 1999.

Kleeman, M. J., Schauer, J. J., and Cass, G. R.: Size and Composition Distribution of Fine Particulate Matter Emitted from Wood Burning, Meat Charbroiling, and Cigarettes, Environ. Sci. Technol., 33, 3516-3523, 1999.

Kleeman, M. J., Riddle, S. G., and Jakober, C. A.: Size distribution of particle-phase molecular markers during a severe winter pollution episode, Environ. Sci. Technol., 42, 6469-6475, 2008.

Offenberg, J. H. and Baker, J. E.: Aerosol size distributions of polycyclic aromatic hydrocarbons in urban and over-water atmospheres, Environ. Sci. Technol., 33, 3324-3331, 1999.

Ohura, T., Amagai, T., Fusaya, M., and Matsushita, H.: Polycyclic Aromatic Hydrocarbons in Indoor and Outdoor Environments and Factors Affecting Their Concentrations, Environ. Sci. Technol., 38, 77-83, 2004.

Oros, D. R. and Simoneit, B. R. T.: Identification and emission rates 
of molecular tracers in coal smoke particulate matter, Fuel, 79, 515-536, 2000.

Pierce, R. C. and Katz, M.: Dependency of polynuclear aromatic hydrocarbon content on size distribution of atmospheric aerosols, Environ. Sci. Technol., 9, 347-353, 1975.

Ramanathan, V. C., Kiehl, J. T., and Rosenfeld, D.: Aerosols, climate, and the hydrological cycle, Science, 294, 2119-2124, 2001.

Riddle, S. G., Robert, M. A., Jakober, C. A., Hannigan, M. P., and Kleeman, M. J.: Size Distribution of Trace Organic Species Emitted From Heavy-Duty Diesel Vehicles, Environ. Sci. Technol., 42, 974-976, 2008.

Rogge, W. F., Hildemann, L. M., Mazurek, M., and Cass, G. R.: Sources of fine organic aerosol, 2. Noncatalyst and catalystequipped automobiles and heavy-dutyl diesel trucks, Environ. Sci. Technol., 27, 636-651, 1993a.

Rogge, W. F., Hildemann, L. M., Mazurek, M. A., and Cass, G. R.: Sources of fine organic aerosol, 4. Particulate abrasion products from leaf surfaces of urban plants, Environ. Sci. Technol., 27, 2700-2711, 1993b.

Seinfeld, J. H. and Pandis, S. N.:Atmospheric Chemistry and Physics, John Wiley and Sons, New York, 1998.

Seinfeld, J. H. and Pankow, J. F.: Organic atmospheric particulate material, Annu. Rev. Phys. Chem., 54, 121-140, 2003.

Simoneit, B. R. T., Sheng, G., Chen, X., Fu, J., Zhang, J., and $\mathrm{Xu}, \mathrm{Y}$.: Molecular marker study of extractable organic matter in aerosols from urban areas of China, Atmos. Environ. A-Gen., 25, 2111-2129, 1991.

Simoneit, B. R. T., Kobayashi, M., Mochida, M., Kawamura, K., and Huebert, B. J.: Aerosol particles collected on aircraft flights over the northwestern Pacific region during the ACE-Asia campaign: Composition and major sources of the organic compounds, J. Geophys. Res.-Atmos., 109, D19S09, doi:10.1029/2004JD004565, 2004a.
Simoneit, B. R. T., Kobayashi, M., Mochida, M., Kawamura, K., Lee, M., Lim, H. J., Turpin, B. J., and Komazaki, Y.: Composition and major sources of organic compounds of aerosol particulate matter sampled during the ACE-Asia campaign, J. Geophys. Res.-Atmos., 109, D19S10, doi:10.1029/2004JD004598., 2004b.

Venkataraman, C., Lyons, J. M., and Friedlander, S. K.: Size Distributions of Polycyclic Aromatic Hydrocarbons and Elemental Carbon, 1. Sampling, Measurement Methods, and Source Characterization, Environ. Sci. Technol., 28, 555-562, 1994.

Venkataraman, C., Negi, G., Brata Sardar, S., and Rastogi, R.: Size distributions of polycyclic aromatic hydrocarbons in aerosol emissions from biofuel combustion, J. Aerosol Sci., 33, 503-518, 2002.

Wang, G. H., Kawamura, K., Lee, S. C., Ho, K. F., and Cao, J. J.: Molecular, seasonal and spatial distributions of organic aerosols from fourteen Chinese cities, Environ. Sci. Technol., 40, 46194625, 2006.

Wang, G. H., Kawamura, K., Zhao, X., Li, Q. G., Dai, Z. X., and Niu, H. Y.: Identification, abundance and seasonal variation of anthropogenic organic aerosols from a mega-city in China, Atmos. Environ., 41, 407-416, 2007.

Yao, X., Lau, A. P. S., Fang, M., Chan, C. K., and Hu, M.: Size distributions and formation of ionic species in atmospheric particulate pollutants in Beijing, China: 2-dicarboxylic acids, Atmos. Environ., 37, 3001-3007, 2003.

Yu, J. Z., Yang, H., Zhang, H., and Lau, A. K. H.: Size distributions of water-soluble organic carbon in ambient aerosols and its size-resolved thermal characteristics, Atmos. Environ., 38, 1061-1071, 2004.

Zheng, M., Kester, D. R., Wang, F., Shi, X., and Guo, Z.: Size distribution of organic and inorganic species in Hong Kong aerosols during the wet and dry seasons, J. Geophys. Res.-Atmos., 113, D16303, doi:10.1029/2007JD009424, 2008. 